\title{
Employability Skills and Trends in the Outdoor Power and Equipment Industry
}

\author{
Antoine J. Alston ${ }^{\mathrm{a}}$, Ryan Anderson ${ }^{\mathrm{b}}$, Chastity W. English ${ }^{\mathrm{c}}$, Dexter B. Wakefield ${ }^{\mathrm{d}}$ \\ ${ }^{\mathrm{a} N o r t h}$ Carolina Agricultural and Technical State University, ${ }^{\mathrm{b} S a u k}$ Valley Community College, ${ }^{\mathrm{c}}$ North Carolina State \\ University, ${ }^{\mathrm{d}}$ Texas State University
}

\begin{abstract}
The Power, Structural, and Technical Systems (PST) Career Pathway is one of eight within the Agriculture, Food, and Natural Resources Career Cluster; this pathway provides the curriculum that includes outdoor power equipment content. The perceived workforce readiness and skills needed in this pathway and related future trends were analyzed for entrylevel jobs within the outdoor power equipment industry. The respondents expressed concern with being able to find qualified entry-level employees. Respondents indicated that the major skill categories of interpersonal skills, communication skills, computer skills, character skills, technical competency, and their corresponding subskills, were important for entry-level employment. The respondents indicated shop experience and general work experience are important for career success, which are experiences that take place through school-based agricultural education. The areas with greatest impact on the future of the industry were equipment technology advancements, urbanization, environmental laws/policies, and the growth of technical education at the secondary and post-secondary level. Secondary agricultural educators and outdoor power equipment dealers should explore developing internships and other partnerships in order to better prepare students for entry-level positions within the outdoor power equipment industry.
\end{abstract}

Keywords: human capital, outdoor power equipment, agricultural education, agricultural mechanics, career preparation

\section{Introduction}

According to Junior Achievement (2013), many questions exist as to whether America's schools are effectively preparing students for work when taking into account existing curriculum and partnerships with the business community. What does it mean to be "workforce ready”? Clark, LeFebvre, Burkum, and Kyte, (2013, p. 15) defined work readiness as "an individual that possesses the foundational skills needed to be minimally qualified for specific occupations as determined through a job analysis or occupational profile.” A plethora of studies (Carnevale \& Desrochers, 2003; Gray \& Herr, 2006) indicate that American businesses believe only half of high school students are equipped with the requisite workplace skills, such as oral and written communication, critical thinking, and problem solving. Through a series of surveys conducted with hiring professionals, the Conference Board Inc. (Casner-Lotto \& Barrington, 2006) found that only $20 \%$ of young job hires were considered to be "very qualified" for their new positions, with $80 \%$ considered to either be in the "somewhat qualified" to "very unqualified" categories. Moreover, it was acknowledged by this same group that K-12 schools should hold the major responsibility for providing the basic knowledge and applied skills for new workers.

What is the workforce readiness of individuals entering the Agricultural, Food, and Natural Resources Career Cluster and specifically its Power, Structural, and Technical Systems Career Pathway? The Power, Structural, and Technical Systems Career Pathway encompasses the study of agricultural equipment, power systems, alternative fuel sources and precision technology, as well as woodworking, metalworking, welding and project planning for agricultural structures. As a branch of Career and Technical Education (CTE), the mission of U.S. school-based agricultural education (SBAE) is to prepare students for "successful careers and a lifetime of informed choices in the global agriculture, food, fiber and natural resources systems" (National FFA Organization, 2016).

Chumbley, Haynes, and Stofer (2015) suggested SBAE programs should focus on preparing students to enter demanding and needed occupations or postsecondary programs. Moreover, Roberts and Ball (2009) stated that SBAE students should acquire skills and competencies that will enable them to gain successful employment. With regard to this study Rasty and Anderson (2017) indicated that agricultural mechanics consists of a wide range of technical skills. In relation to skill sets, Slusher, Robinson, \& Edwards (2011) found 
several soft-skills outranked many of the technical skills deemed necessary for entry-level employment. One interesting point found by Slusher et al. suggested that entry-level skill should be identified by geographical location in order to produce technical skills preferred by employers in their respective states. Slusher et al. further indicated that adjustments to curriculum should be made so SBAE graduates receive the appropriate instruction preparing them for future employment.

Trends in the Outdoor Power Equipment Industry. According to RnR Marketing Research (2017), the overall commercial demand for outdoor power equipment is expected to grow at a somewhat faster pace than consumer product sales in the future. This is due mostly to an increased rebound in demand by landscaping firms. Moreover, an increase in landscaping service revenue is expected, which will accelerate through 2017 and afterword, causing landscapers to hire additional personnel and invest in new equipment, and aid them in capitalizing on the growth opportunities (RnR Marketing Research, 2017). Further, the United States' demand for power lawn and garden equipment is expected to increase by $3.2 \%$ annually to $\$ 11.7$ billion in 2019. Hedge trimmers and turf and grounds equipment are expected to be the highest growth area, while lawnmowers remain the largest segment of the industry. In addition, market trends show that the anticipated growth in the commercial market outdoor power equipment will continue to outpace the bigger residential segment through 2019 (RnR Marketing Research, 2017).

With regard to technological trends, many trends will significantly influence the power lawn and garden equipment market, with none greater than the introduction of more electric equipment, especially battery-powered units, in both the residential and commercial markets (RnR Marketing Research, 2017). Although some residential equipment has been powered by batteries for many years, improvements in battery technology will drive increased sales of larger units that use this power source, especially riding lawnmowers. The overall demand for robotic mowers is also expected to rise significantly through 2017 and beyond, as consumers increasingly opt for the convenience of these units as their performance improves and prices decline (RnR Marketing Research, 2017). According to a 2016 national industry survey (RnR Marketing Research, 2017), the biggest concerns that outdoor power equipment dealers had were the cost of operating their businesses and the availability of quality employees. Further, more than $96 \%$ of dealers stated that a shortage of qualified service technicians existed for the OPE industry, which correlated with the increases in shop labor and service technician pay rates in recent years.

\section{Conceptual and Theoretical Framework}

For the purposes of this study, human capital theory (Goode, 1959) served as its theoretical framework and the Secretary's Commission on Achieving Necessary Skills (SCANS) Report (2006) provided a conceptual framework.

Human Capital. Human capital theory served as the theoretical framework for this study. According to Simonson and Thompson (1997), theories overall have two main purposes with regard to knowledge: (a) to provide a direction for future research, and (b) to provide direction to the practice of a profession. Scholars differ on how human capital is defined. Goode (1959) defined human capital as the knowledge, skills, attitudes, aptitudes, and required traits contributing to overall production. Van Loo and Rocco (2004) indicated that human capital theory should be considered an investment in human resources for employees to possess the necessary "skills and knowledge" (p. 99), and Swanson (2001) defined human capital as an investment in people. Both Van Loo and Rocco and Swanson indicated that this investment is often useful to enhance knowledge and skills of employees for increasing worker output. The economist Gary Becker provided further refinement to the human capital theory in 1962, in his book entitled Human Capital (1993) stating that "education and training are the most important investments in human capital” (p. 17).

Bowles, Gintis, and Osborne (2001) asserted that skills represent individual capacities contributing to production as an argument for the production function. Moreover, Blundell, Dearden, Meghir, and Sianesi (1999) found that two main components of human capital are highly correlated: early ability (whether acquired or innate) and skills acquired through formal education or training on the job. It is important to note that human capital greatly differs from other assets, essentially because it yields market returns only in proportion to the worker's supply of labor (Hall \& Johnson, 1980). According to Becker (1993), human capital theory is the most influential economic theory of Western education, particularly with its influence on the workplace.

SCANS Framework. In 1990, the United States Department of Labor conducted a study to gauge how well schools prepared young people for the workforce. This was a historic event in that it was the first time American businesses were given a voice to clearly state to educators what students needed to know to be successful in the workplace (The Secretary's Commission on Achieving Necessary Skills (SCANS) Report, 2006). TheSCANS Report (2006) outlined and examined the demands of the nation's workplace and concluded that more than one-half of American youth matriculated from high school without the knowledge or foundation required to find and hold a good job. Due to 
this report, major changes were made in education as cognizant officials faced the reality that students were not receiving what they needed to be prepared and successful in the global workforce of the 21st century.

A major goal of the report was to present the necessary functional and enabling skills that society must offer to every child by age 16 (SCANS, 2006). The SCANS staff conducted studies of cognitive science research literature related to the importance of learning in context, met with cognitive scientists, and subsequently advocated the teaching of skills within the functional context of the workplace. This represented what the commission termed the most radical change in educational content in the 20th century. The Secretary's Commission on Achieving Necessary Skills (SCANS) Report (2006) consisted of a three-part foundation component and five workplace competencies. The three foundation skills were basic skills (reading, writing, arithmetic/mathematics, listening, speaking), thinking skills (creative thinking, decision-making, problem solving, seeing things in the mind's eye, knowing how to learn, reasoning), and personal qualities (responsibility, self-esteem, sociability, self-management, integrity/honesty).

The report designated five competencies that effective workers must possess. The specific competencies included the categories of Resources, Interpersonal, Information Management, Systems, and Technology. The Resource Competency included the sub skills of time, money, materials and facilities, human resources. The Interpersonal Competency encompasses participating as a Member of a Team, Teaching Others New Skills, Servicing Clients/Customers, Exercising Leadership, Negotiating, and Working with Diversity. The competency of Information Management, involves Acquiring and Evaluating Information, Organizing and Evaluating Information, Interpreting and Communicating Information, and Using Computers to Process Information. The Systems Competency includes Understanding Systems, Monitoring and Correcting Performance, and Improving or Designing a System. The final competence of Technology specifies the ability to Itemized Select Technology, Applying Technology, and Maintaining and Troubleshooting Equipment.

Literature Summary. The outdoor power equipment industry is an essential sector of the Agriculture, Food, and Natural Resources Career Cluster. For this study, human capital theory and the SCANS Report provide a foundational basis with regard to the rationale for required workplace knowledge and skills in this industry. As with any industry there are certain skill sets that are required for workplace success, particularly at the entry levels. Some skills sets are transferable across industries, while others are more job specific. Regardless of the industry, knowledge, skills, attitudes, aptitudes, and required traits contributing to overall production must be determined for entry-level employment success (Chumbley, Haynes, \& Stofer, 2015).

\section{Purpose and Objectives}

It is vital that the skills taught in agricultural education remain up-to-date in order to prepare students with the proper 21st century skills needed for employment (Davis \& Jayaratne, 2015). Roberts, Harder, and Brashears (2016) indicated that advances within industry have helped to drive and dictate the need for skilled and knowledgeable future members of the industrial workforce. The purpose of this research study was to determine the importance of workplace knowledge, skills, and abilities for entrylevel jobs in the outdoor power and equipment industry.

This research purpose aligns with the National Career and Technical Education Research Agenda (Lambeth, Elliot, \& Joerger, 2008) research problem area 2: Curricula and Program Planning. This research problem area specifically relates to the research objectives 2.2 Curricula Designs and 3.1 Best Practices. The specific research activities addressed included 2.2.1 Needs of Future Workforce. The purpose of this study is also aligned with the National Research Agenda (NRA) of the American Association for Agricultural Education (AAAE). Specifically, the present study aligns with Research Priority 5 of the AAAE NRA, Efficient and Effective Agricultural Education Programs.

Three objectives guided this study:

1. Identify how prepared entry-level employees were when evaluating workplace knowledge, skills, and abilities in the outdoor power and equipment industry;

2. Determine the perceived level of importance life experience has on the hiring process for entry-level positions in the outdoor power and equipment industry;

3. Identify perceived trends/issues likely to influence the outdoor power and equipment industry in the future.

\section{Methodology}

The population for this descriptive survey research study consisted of a multistate network of 542 outdoor power equipment dealers including the states of North Carolina, South Carolina, Virginia, Tennessee, Maryland, and Delaware. Due to the number of subjects $(N=542)$ and the ease of electronic data collection, a random sample was selected and a representative sample size was selected $(n=185)$ based on recommendations from Krejcie and Morgan (1970). These participants were then randomly selected using a random number generator (Urbaniak \& Plous, 2014) and assigned an identification number.

The survey instrument for this study was adapted and modified from Graham (2001) and Alston, Cromartie, Warren-English, and Wakefield (2009) and consisted of four sections. Section one was designed to 
gauge the opinion of outdoor power equipment dealers regarding the importance of and level of preparation needed for entry-level jobs in the outdoor power equipment industry. Section two was designed to gauge the perceived importance of prior experience for entrylevel employee career success in the outdoor power equipment industry. Section three was designed to rate specific issues likely to influence or change the outdoor power equipment industry during the next five to ten years. Last, section four gathered information with respect to personal and professional characteristics desirable among job candidates.

The instrument's content and face validity were established using a panel of experts. Brown (1983) defines content validity as "the degree to which items on a test representatively sample the underlying content domain” (p. 487). Brown recommends using expert judges as a means of establishing content validity. Bornstein (1996) defines face validity as the extent to which a process, specifically an assessment or psychological test, is effective in terms of measuring a specific construct. Face validity was established with the aid of a panel of expert agricultural education scholars who served to review the instrument for face and content validity, and ultimately determined that this instrument was suitable for use within this study.

Reliability assures the dependability or precision of an instrument. A pilot test was conducted to establish the reliability of the survey instrument. The pilot test was conducted with 25 outdoor power equipment dealers from the initial population, which were not included in the final survey sample; 20 dealers responded. Cronbach's alpha was used as the reliability measure for this study. Nunnally (1967) suggested that 0.5 to 0.6 would be high enough in the early stages of research. The 0.8 measure is a frequently used reliability measurement, and measurements of 0.9 might not be high enough where precision is needed. Cronbach's alpha reliability coefficients for the survey instrument were as follows: Section $1=0.91$, Section $2=0.89$, and Section $3=0.92$. No adjustments were made to the survey instrument as result of the reliability analysis.

A three-round, web-based questionnaire approach was used for this study. A total of 185 randomly selected outdoor power equipment dealers were surveyed. Elements of Dillman's tailored design method (2009) were utilized to achieve an optimal return rate. An initial electronic letter was sent informing the potential respondents that they would receive an invitation by electronic mail with a link to the survey instrument in approximately two weeks. By the end of week one, the researchers had received 42 completed surveys. After week one had passed a reminder message was sent, and by the end of week two, 25 more responses had been received. A final message was sent resulting in 18 more responses. Overall, a final return rate of $45 \%(n=85)$ was accomplished. Non-response error was a relevant concern; to control for non-response error, Miller and Smith (1983) recommend comparing early and late respondents. Therefore, procedures for handling nonrespondents were followed as outlined as Method 1 in Lindner, Murphy, and Briers (2001). An independent samples $t$-test indicated that no significant differences ( $p$ $<.05$ ) existed between the early and late respondents. With regard to data analysis, when taking into account the descriptive nature of this study and the stated objectives, it was determined that descriptive measures such as means and frequencies would be appropriate.

\section{Findings}

The respondents were on average 55 year-old white males, with the majority possessing an associate's degree, followed by a high school diploma, then a bachelor's degree. Only four respondents had earned a graduate degree. A majority of the respondents were from North Carolina, followed by West Virginia, Virginia, and Tennessee, with other states only having a few respondents. Table 1 presents selected personal characteristics of the survey respondents.

Table 1. Outdoor Power Equipment Dealers’ Selected Personal Characteristics $(n=84)$

\begin{tabular}{|c|c|c|c|}
\hline Variables & $f$ & Mean & Percent \\
\hline Age & 84 & 55.66 & \\
\hline \multicolumn{4}{|l|}{ Gender } \\
\hline Female & 0 & & 0.0 \\
\hline Male & 84 & & 100 \\
\hline \multicolumn{4}{|l|}{ Race/Ethnicity } \\
\hline Black & 0 & & 0.0 \\
\hline White & 84 & & 100 \\
\hline Hispanic & 0 & & 0.0 \\
\hline Native American & 0 & & 0.0 \\
\hline Asian/Pacific Islander & 0 & & 0.0 \\
\hline Other & 0 & & 0.0 \\
\hline \multicolumn{4}{|l|}{ Education } \\
\hline High school & 24 & & 28.8 \\
\hline $\begin{array}{l}\text { Post-secondary certificate/ } \\
\text { training program }\end{array}$ & 12 & & 14.2 \\
\hline Associate’s degree & 29 & & 34.5 \\
\hline Bachelor's degree & 15 & & 17.8 \\
\hline Master's degree & 4 & & 4.7 \\
\hline Doctorate & 0 & & 0.0 \\
\hline \multicolumn{4}{|l|}{$\begin{array}{l}\text { State in which Dealership is } \\
\text { Located }\end{array}$} \\
\hline North Carolina & 29 & & 34.5 \\
\hline Virginia & 15 & & 17.8 \\
\hline South Carolina & 5 & & 5.9 \\
\hline Delaware & 7 & & 8.3 \\
\hline West Virginia & 19 & & 22.6 \\
\hline Tennessee & 8 & & 9.5 \\
\hline Maryland & 1 & & 1.1 \\
\hline
\end{tabular}


Table 2 provides selected demographics for the respondents. On average, the respondents had worked in the industry for 31 years. A majority of the respondents were either the dealership owner or service manager. The average dealership employed eight individuals. For the roles of technician, sales, service manager, and manager, the average dealership expected to retire and hire at least one person in each of the categories within the next five years.

Table 2. Outdoor Power Equipment Dealers' Selected Dealership Demographics ( $n=84$ )

\begin{tabular}{lcc}
\hline Dealership demographics & $f$ & Mean \\
\hline $\begin{array}{l}\text { Years worked in the outdoor power } \\
\text { equipment industry }\end{array}$ & & 31.22 \\
Current role at dealership & 2 & \\
$\quad$ Technician & 7 & \\
$\quad$ Sales & 52 \\
$\quad$ Service Manager & 8.87 \\
$\quad$ Owner & \\
Employees at dealership & 2.37 \\
Individuals expected to retire in the & 1.24 \\
next five years at the dealership & 1.20 \\
$\quad$ Technician & 1.51 \\
$\quad$ Sales & \\
$\quad$ Service Manager & \\
$\quad$ Owner & \\
Anticipated hires/replacements in & \\
each area within the next five years & \\
at the dealership & \\
$\quad$ Technician & \\
$\quad$ Sales & \\
$\quad$ Service Manager & 1.72 \\
Owner & 1.33 \\
\hline
\end{tabular}

Objective One Findings Table 3 provides the findings with regard to the levels of importance and levels of preparation for the interpersonal skills of entry-level employees as perceived by outdoor power equipment dealers. Decision-making and problem solving were found to be very important, with entry-level employees perceived to be prepared on them. Management skills were found to be important, with employees' preparation level somewhat prepared. Organizational skills were also found to be important, with employees' level of preparation perceived to be prepared. Leadership skills were found to be important, but the dealers' employees level of preparation was only somewhat prepared. Initiative was perceived to be very important and the employees' level of preparation was prepared. The skills of teamwork, dedication, and appearance were found to very important, with the employees' level of preparation viewed as prepared. Work ethic was found to be the only interpersonal skill to be extremely important and the employees' level of preparation perceived to be prepared.
Table 3. Level of Importance and Preparation of Interpersonal Skills Possessed by Entry-Level Outdoor Power and Equipment Employees $(n=85)$

\begin{tabular}{|c|c|c|}
\hline Interpersonal skills & $\begin{array}{c}\text { Level of } \\
\text { importance* }\end{array}$ & $\begin{array}{c}\text { Level of } \\
\text { preparation** }\end{array}$ \\
\hline 1. Work ethic & 4.62 & 3.31 \\
\hline 2. Initiative & 4.45 & 2.93 \\
\hline 3. Dedication & 4.40 & 3.19 \\
\hline 4. Teamwork & 4.33 & 3.19 \\
\hline 5. Appearance & 3.88 & 3.17 \\
\hline $\begin{array}{l}\text { 6. Problem } \\
\text { solving }\end{array}$ & 3.86 & 2.79 \\
\hline $\begin{array}{l}\text { 7. Organizational } \\
\text { skills }\end{array}$ & 3.60 & 2.64 \\
\hline $\begin{array}{l}\text { 8. Decision } \\
\text { making }\end{array}$ & 3.57 & 2.69 \\
\hline 9. Leadership & 3.00 & 2.31 \\
\hline $\begin{array}{l}\text { 10. Management } \\
\text { skills }\end{array}$ & 2.76 & 2.21 \\
\hline \multicolumn{3}{|c|}{$\begin{array}{l}\text { *Scale: } 1.00-1.49=\text { Unimportant, } 1.50-2.49=\text { Somewhat } \\
\text { unimportant, } 2.50-3.49=\text { Important, } 3.50-4.49=\text { Very } \\
\text { important, } 4.50-5.00=\text { Extremely important } \\
\text { **Scale: } 1.00-1.49=\text { Unprepared, } 1.50-2.49=\text { Somewhat } \\
\text { prepared, } 2.50-3.49=\text { Prepared, } 3.50-4.49=\text { Good } \\
\text { preparation, } 4.50-5.00=\text { Thoroughly prepared }\end{array}$} \\
\hline
\end{tabular}

Table 4 provides findings with regard to the level of importance and level of preparation for the communication skills of entry-level employees as perceived by outdoor power equipment dealers. Listening was perceived to b e extremely important, with employees' level of preparation as prepared. The skills of understanding instruction, and verbalizing were considered to be important, and employees' level of preparation viewed as prepared. As for technical writing, it was also judged to be important, but found to be at the somewhat prepared level. With regard to second language, it was considered to be somewhat unimportant, and perceived to be at the somewhat prepared level. Last, customer service was considered to be very important and the level of employees' preparation as prepared. 
Table 4. Level of Importance and Preparation of Communication Skills Possessed by Entry-Level Outdoor Power and Equipment Employees $(n=85)$

\begin{tabular}{|c|c|c|}
\hline $\begin{array}{l}\text { Communication } \\
\text { skills }\end{array}$ & $\begin{array}{c}\text { Level of } \\
\text { importance* }\end{array}$ & $\begin{array}{c}\text { Level of } \\
\text { preparation** }\end{array}$ \\
\hline 1. Listening & 4.55 & 3.10 \\
\hline $\begin{array}{l}\text { 2. Understanding } \\
\text { instruction }\end{array}$ & 4.38 & 3.10 \\
\hline $\begin{array}{l}\text { 3. Overall } \\
\text { customer } \\
\text { service }\end{array}$ & 4.36 & 3.21 \\
\hline 4. Verbalizing & 4.05 & 3.10 \\
\hline $\begin{array}{l}\text { 5. Technical } \\
\text { writing }\end{array}$ & 2.88 & 2.19 \\
\hline $\begin{array}{l}\text { 6. Second } \\
\text { language }\end{array}$ & 2.00 & 1.57 \\
\hline \multicolumn{3}{|c|}{$\begin{array}{l}\text { *Sale: } 1.00-1.49=\text { Unimportant, } 1.50-2.49=\text { Somewhat } \\
\text { unimportant, } 2.50-3.49=\text { Important, } 3.50-4.49=\text { Very } \\
\text { important, } 4.50-5.00=\text { Extremely important } \\
\text { **Scale: } 1.00-1.49=\text { Unprepared, } 1.50-2.49=\text { Somewhat } \\
\text { prepared, } 2.50-3.49=\text { Prepared, } 3.50-4.49=\text { Good } \\
\text { preparation, } 4.50-5.00=\text { Thoroughly prepared }\end{array}$} \\
\hline
\end{tabular}

Table 5 provides the findings with regard to the level of importance and level of preparation for the computer skills of entry-level employees as perceived by outdoor power equipment dealers. With regard to word processing skills, the level of importance was judged important, with the level of preparation found to be prepared. As for spreadsheets, the level of importance was found to be somewhat important and employees' preparation level was somewhat prepared. Internet access and use was judged very important and the level of employees’ perceived preparation was prepared.

Table 5. The Level of Importance and Preparation of Computer Skills Possessed by Entry-Level Outdoor Power and Equipment Employees $(n=85)$

\begin{tabular}{lcc}
\hline Computer skills & $\begin{array}{c}\text { Level of } \\
\text { importance } *\end{array}$ & $\begin{array}{c}\text { Level of } \\
\text { preparation** }\end{array}$ \\
\hline $\begin{array}{l}\text { 1. Internet access } \\
\text { and use }\end{array}$ & 3.93 & 3.49 \\
$\begin{array}{l}\text { 2. Word } \\
\text { processing }\end{array}$ & 2.71 & 2.59 \\
3. Spreadsheets & 2.37 & 2.29
\end{tabular}

*Scale: $1.00-1.49$ = Unimportant, 1.50-2.49 = Somewhat unimportant, 2.50-3.49 = Important, 3.50-4.49 = Very important, 4.50-5.00 = Extremely important **Scale: $1.00-1.49$ = Unprepared, $1.50-2.49$ = Somewhat prepared, 2.50-3.49 = Prepared, 3.50-4.49 = Good preparation, 4.50-5.00 = Thoroughly prepared
Table 6 provides the findings with regard to the level of importance and level of preparation for the character traits of entry-level employees as perceived by outdoor power equipment dealers. Honesty was perceived to be extremely important, with the employees' level of preparation being perceived as good preparation. The trait of dependability was found to be extremely important as well, and employees' level of preparation was deemed prepared. Moreover, the trait of integrity was also perceived to be extremely important, with a level of good preparation found for it.

Table 6. The Level of Importance and Preparation of Character Traits Possessed by Entry-Level Outdoor Power and Equipment Employees $(n=85)$

\begin{tabular}{lcc}
\hline Character traits & $\begin{array}{c}\text { Level of } \\
\text { importance* }\end{array}$ & $\begin{array}{c}\text { Level of } \\
\text { preparation** }\end{array}$ \\
\hline 1. Integrity & 4.85 & 3.63 \\
2. Honesty & 4.85 & 3.83 \\
3. Dependability & 4.66 & 3.44 \\
\hline
\end{tabular}

*Scale: $1.00-1.49$ = Unimportant, 1.50-2.49 = Somewhat unimportant, 2.50-3.49 = Important, 3.50-4.49 = Very important, 4.50-5.00 = Extremely important **Scale: $1.00-1.49$ = Unprepared, $1.50-2.49$ = Somewhat prepared, 2.50-3.49 $=$ Prepared, 3.50-4.49 $=$ Good preparation, $4.50-5.00=$ Thoroughly prepared

Table 7 provides the findings with regard to the level of importance and level of preparation for the technical competency of entry-level employees as perceived by outdoor power equipment dealers. With regard to skills string trimmer maintenance, chainsaw maintenance, backpack blower maintenance, push mower maintenance, and power generator maintenance, all were found to be important, with employees' levels of preparation judged as prepared for all skills. As for troubleshooting, it was found to be very important, with the employees' preparation levels judged to be prepared. Riding lawnmower maintenance skill was found to be important, and the employees' preparation level perceived to be prepared. Knowledge of 4-stroke and 2stroke engine theory was found to be very important, with the employees' preparation level for both perceived to be prepared. 
Table 7. The Level of Importance and Preparation of Technical Competency Possessed by Entry-Level Outdoor Power and Equipment Employees $(n=85)$

\begin{tabular}{|c|c|c|}
\hline $\begin{array}{l}\text { Technical } \\
\text { competency }\end{array}$ & $\begin{array}{c}\text { Level of } \\
\text { importance* }\end{array}$ & $\begin{array}{c}\text { Level of } \\
\text { preparation** }\end{array}$ \\
\hline 1. Troubleshooting & 4.07 & 2.80 \\
\hline $\begin{array}{l}\text { 2. Riding lawn } \\
\text { mower } \\
\text { maintenance }\end{array}$ & 3.73 & 2.93 \\
\hline $\begin{array}{l}\text { 3. 2-stroke engine } \\
\text { theory }\end{array}$ & 3.73 & 2.68 \\
\hline $\begin{array}{l}\text { 4. 4-stroke engine } \\
\text { theory }\end{array}$ & 3.71 & 2.71 \\
\hline $\begin{array}{l}\text { 5. Push lawn } \\
\text { mower } \\
\text { maintenance }\end{array}$ & 3.49 & 2.80 \\
\hline $\begin{array}{l}\text { 6. String trimmer } \\
\text { maintenance }\end{array}$ & 3.46 & 2.76 \\
\hline $\begin{array}{l}\text { 7. Chainsaw } \\
\text { maintenance }\end{array}$ & 3.46 & 2.76 \\
\hline $\begin{array}{l}\text { 8. Backpack blower } \\
\text { maintenance }\end{array}$ & 3.46 & 2.73 \\
\hline $\begin{array}{l}\text { 9. Power generator } \\
\text { maintenance }\end{array}$ & 3.32 & 2.54 \\
\hline $\begin{array}{l}\text { 10. Pressure masher } \\
\text { maintenance }\end{array}$ & 3.20 & 2.41 \\
\hline \multicolumn{3}{|c|}{$\begin{array}{l}\text { *Scale: } 1.00-1.49=\text { Unimportant, } 1.50-2.49=\text { Somewhat } \\
\text { unimportant, } 2.50-3.49=\text { Important, 3.50-4.49 = Very } \\
\text { important, } 4.50-5.00=\text { Extremely important } \\
\text { **Scale: } 1.00-1.49=\text { Unprepared, } 1.50-2.49=\text { Somewhat } \\
\text { prepared, } 2.50-3.49=\text { Prepared, 3.50-4.49 = Good } \\
\text { preparation, } 4.50-5.00=\text { Thoroughly prepared. }\end{array}$} \\
\hline
\end{tabular}

Objective Two Findings. Table 8 provides the findings with regard to the level of importance of prior life experiences when hiring entry-level employees for the outdoor power equipment industry. The life experiences of reared on a farm, work experiences on a farm, agricultural employment, and being bilingual were judged somewhat unimportant with regard to being hired for entry-level jobs in the outdoor power equipment industry. Shop experience and participation in schoolbased agricultural education or trade and industrial education program were found to be important, and general work experience was viewed as very important for entry-level employment in the outdoor power equipment industry.
Table 8. The Level of Importance of Prior Selected Life Experiences Possessed by Entry-Level Outdoor Power and Equipment Employees $(\mathrm{n}=85)$

\begin{tabular}{lc}
\hline Life experiences & $\begin{array}{c}\text { Level of } \\
\text { Importance }\end{array}$ \\
\hline 1. General work experience & 3.63 \\
2. Shop experience & 3.34 \\
3. Participation in school-based & 2.54 \\
$\quad$ agricultural education or trade & \\
and industrial education program & \\
4. Work experiences on a farm & 1.93 \\
5. Reared on a farm & 1.88 \\
6. Agricultural employment & 1.83 \\
7. Bilingual & 1.83 \\
*Scale: $1.00-1.49=$ Unimportant, 1.50-2.49 = Somewhat \\
unimportant, $2.50-3.49=$ Important, 3.50-4.49 = Very \\
important, $4.50-5.00=$ Extremely important
\end{tabular}

Objective Three Findings. Table 9 provides the findings with regard to the dealers' perceived trends/issues that will influence the outdoor power equipment industry in the future. Urbanization was found to have an influence upon the outdoor power equipment industry. The following items were found to be very influential with regard to the future of the outdoor power equipment industry: environmental laws/policies, outdoor power equipment technology education program growth at technical/community colleges, equipment technology advancements, fuel standards, growth of technical programs at the secondary education level, and safety regulations.

Table 9. Perceived Trends/Issues Likely to Influence the Outdoor Power and Equipment Industry in the Future $(\mathrm{n}=85)$

\begin{tabular}{lc}
\hline Trends/issues areas & Level of influence \\
\hline 1. Fuel standards & 4.15 \\
2. Equipment technology & 4.00 \\
advancements & \\
3. Environmental laws/policies & 3.71 \\
4. Safety regulations & 3.54 \\
5. Growth of technical & 3.51 \\
programs at the secondary & \\
education level & 3.49 \\
6. Outdoor power equipment & \\
technology education & \\
program growth at & \\
technical/community & \\
colleges & 3.10 \\
7. Urbanization & \\
Scale: $1.00-1.49=$ No influence, 1.50-2.49 = Some \\
influence, $2.50-3.49=$ Influential, 3.50-4.49= Very \\
influential, $4.50-5.00=$ Extremely influential
\end{tabular}




\section{Conclusions, Implications, and Recommendations}

This study analyzed the importance of work place knowledge, skills, and abilities for entry-level jobs in the outdoor power and equipment industry, a major sector of the Agriculture, Food and Natural Resources Career Cluster. With regard to the major categories interpersonal skills, communication skills, computer skills, character skills, and technical competency, and their corresponding subskills, they were overwhelmingly found to be either important to extremely important. This is in alignment with the Secretary's Commission on Achieving Necessary Skills (SCANS) Report (2006), with regard to the skill sets important for job success across all professions. Moreover, it was found that entry-level employees were perceived to be prepared for the most part across all categories. Even though the preparation level was considered adequate across all skill areas, qualitative comments provided from many respondents indicated that procuring quality entry-level talent is still a major concern, which in direct agreement with the national industry survey conducted by RnR Marketing Research (2017).

Respondents were asked the importance of various life skills in relation to entry-level employee success in the outdoor power equipment industry. It was found that general work experience and shop experience were important for entry-level job success, but experiences such as being reared on a farm, agricultural employment, and participation in secondary agricultural or trade and industrial programs were found to be less important. Perhaps this can be contributed to the general public's disconnect from agriculture and a lack of understanding of the benefits of career and technical education, and specifically agricultural education, by the respondents.

One area of interest for researchers was which growth areas/issues did respondents percieve would impact the outdoor power equipment industry over the next five to ten years. The specific areas that were expected to have an influence were environmental laws/policies, urbanization, outdoor power equipment technology program growth at technical/community colleges, equipment technology advancements, and fuel standards. The findings are supported by the research from RnR Marketing Research (2017) regarding outdoor power equipment industry trends. Of interest, respondents indicated that growth of technical programs at the secondary education level were a trend that would influence the industry, but in contrast they also indicated that secondary agricutlural or trade and industrial program experience were not important for entry-level job success to the industry. This, as stated previously, would indicate a lack of understanding of the full scope of career and technical education and all of its benefits by respondents, which could be an issue for career and techincal educators but also an opportunity to educate and form parternships with industry to alleviate this barrier.

Publications in the Chronicle of Higher Education (Gonzalez, 2012) and Time Magazine (Klein, 2012) emphasize the fact that overall renewed interest in career and technical education has climbed as policymakers and educators recognize its potential to enhance student engagement, improve graduation rates, and ensure college and career readiness. During the 2010-2011 school year, more than 7 million secondary students took at least one credit of CTE, and 3 million were enrolled in multiple CTE credits (Association of Career and Technical Education, 2014). In 2013, the United States Department of Education called for a high school redesign initiative that encouraged the use of models that are rigorous, relevant, and better focused on real-world experiences. With this call were provisions for highquality college and career exploration, in addition to opportunities for high school students to earn postsecondary credit and career-related experiences, including internships and mentoring, as well as projectbased learning and other work-based learning experiences. These are perhaps opportunities that secondary agricultural educators and outdoor power equipment dealers could explore to better prepare students for entry-level positions in the outdoor power equipment industry.

Overall, this study sheds light on factors to consider in career and technical education and the discipline of agricultural education. With the Power, Structural, and Technical Systems Career Pathway being a major component of the Agricultural, Food, and Natural Resources Career Cluster and SBAE curriculum as a whole, it is imperative that students matriculating through these programs acquire the knowledge, skills, and dispositions needed for entrylevel employee success in an essential agricultural industry sector.

\section{References}

Association for Career \& Technical Education. (2014). What is career and technical education? Retrieved from https://www.acteonline.org/why-cte/what-iscte/

Alston, A., Cromartie, D., Warren-English, C., \& Wakefield, D. (2009). The importance of employability skills as perceived by the employers of United States' land-grant college and university graduates. Journal of Southern Agricultural Education Research, 59(1), 56-69.

Becker, G. S. (1993). Human capital: A theoretical and empirical analysis with special reference to education (3rd ed.). Chicago, IL: University of Chicago Press.

Blundell, R., Dearden, L., Meghir, C., \& Sianesi, B. (1999). Human capital investment: The returns 
from education and training to the individual, the firm and the economy. Fiscal Studies, The Journal of Applied Public Economics, 20(1), 1-23. https://doi.org/10.1111/j.1475-5890.1999.tb00001.x

Bornstein, R. F. (1996). Face validity in psychological assessment: Implications for a unified model of validity. American Psychologist, 51(9), 983-984.

Bowles, S., Gintis, H., \& Osborne, M. (2001). The determinants of earnings: A behavioral approach. Journal of Economic Literature, 39(4), 1137-1176. https://doi.org/10.1257/jel.39.4.1137

Brown, F. G. (1983). Principles of educational and psychological testing (3rd ed.). New York, NY: Holt, Rinehart and Winston.

Carnevale, A. P., \& Desrochers, D. M. (2003). Preparing students for the knowledge economy: What school counselors need to know. Professional School Counseling, 6(4), 228-236.

Casner-Lotto, J., \& Barrington, L. (2006). Are they really ready to work? Conference Board, Inc., Partnership for 21st Century Skills, Corporate Voices for Working Families, and Society for Human Resource Management. Retrieved from http://www.p21.org/storage/documents/FINAL_RE PORT_PDF09-29-06.pdf

Chumbley, S. B., Haynes, J. C., \& Stofer, K. A. (2015). A measure of students' motivation to learn science through agricultural STEM emphasis. Journal of Agricultural Education, 56(4). 107-122. https://doi.org/10.5032/jae.2015.04107

Clark, H., LeFebvre, M., Burkum, K., \& Kyte, T. (2013). Work readiness standards and benchmarks: The key to differentiating America's workforce and regaining global competitiveness. Iowa City, IA: ACT. Retrieved from http://www.act.org/content/dam/act/unsecured/ documents/Work-Readiness-Standards-andBenchmarks.pdf

Davis, R. J., \& Jayaratne, K. S. U. (2015). In-service training needs of agriculture teachers for preparing them to be effective in the 21st century. Journal of Agricultural Education, 56(4), 47-58. https://doi.org/10.5032/jae.2015.04047

Dillman, D. A., Smyth, J. D., \& Christian, L. M. (2009). Internet, mail, and mixed-mode surveys: The tailored design method. Hoboken, NJ: John Wiley \& Sons, Inc.

Gonzalez, J. (2012, September 17). Career and technical education, a key to good jobs, needs help, report says. Chronicle of Higher Education. Retrieved from http://chronicle.com/article/CareerTechnical/ 134504/

Goode, R. B. (1959). Adding to the stock of physical and human capital. The American Economic Review, 49(2), 147-155.

Graham, D. (2001). Employer perception of the preparation of agricultural and extension education graduates. Journal of Southern Agricultural Education Research, 51(1), 88-101. Retrieved from
http://www.jsaer.org/pdf/vol51Whole.pdf

Gray, K. C., \& Herr, E. L. (2006). Other ways to win: Creating alternatives for high school graduates (3rd ed.). Thousand Oaks, CA: Corwin Press.

Hall, A., \& Johnson, T. R. (1980). The determinants of planned retirement age. Industrial and Labor Relations Review, 33(2), 241-254. https://doi.org/10.1177/001979398003300208

Junior Achievement. (2013). Are students prepared for the workplace? New tools for a new generation. Retrieved from https://www.juniorachievement.org/ documents/20009/20652/Are+Students+Prepared+f or+the+Workplace.pdf/c1b75524-016d-4bd1-b8aa74395f51021a

Klein, J. (2012, May 14). Learning that works. TIME. Retrieved from http://content.time.com/time/ magazine/article/0,9171,2113794,00.html

Krejcie, R. V., \& Morgan, D. W. (1970). Determining sample size for research activities. Educational and Psychological Measurement, 30, 607-610. https://doi.org/10.1177/001316447003000308

Lambeth, J. M., Elliot, J., \& Joerger, R. M. (2008). The national career and technical education research agenda. Techniques, 83(7), 52-55.

Lindner, J. R., Murphy, T. H., \& Briers, G. E. (2001). Handling nonresponse in social science research. Journal of Agricultural Education, 42(4), 43-52. https://doi.org/10.5032/jae.2001.04043

Miller, L. E., \& Smith, K. L. (1983). Handling nonresponse issues. Journal of Extension, 21(5), 45-50. Retrieved from https://www.joe.org/joe/ 1983september/83-5-a7.pdf

National FFA Organization. (2016). The agricultural education mission. Retrieved from https://www.ffa.org/about/agricultural-education

Nunnally, J. C. (1967). Psychometric theory. New York, NY: McGraw Hill Book Co. Inc.

Rasty, J., \& Anderson, R. (2017). The importance of agricultural mechanics skills training: implications for agricultural education. Paper presented at American Association of Agricultural Education Conference. San Luis Obispo, CA.

Roberts, T. G., \& Ball, A. L. (2009). Secondary agricultural science as content and context for teaching. Journal of Agricultural Education, 50(1), 81-91. https://doi.org/10.5032/jae.2009.01081

Roberts, T. G., Harder, A., \& Brashears, M. T. (Eds). (2016). American Association for Agricultural Education national research agenda: 2016-2020. Gainesville, FL: Department of Agricultural Education and Communication. RnR Market Research. (2017). Power lawn and garden equipment to 2017. Retrieved from http://www.rnrmarketresearch.com/power-lawnand-garden-equipment-to-2017-marketreport.html

Secretary's Commission on Achieving Necessary Skills. (2006). What work requires of schools: A SCANS report for America 2000. Washington, DC: U.S. 
Department of Labor.

Simonson, M. R., \& Thompson, A. (1997). Educational computing foundations. Columbus, $\mathrm{OH}$ : Merrill/Prentice Hall.

Slusher, W. L., Robinson, J. S., \& Edwards, M. C. (2011). Assessing the animal science technical skills needed by secondary agricultural education graduates for employment in the animal industries: A modified Delphi study. Journal of Agricultural Education, 52(2), 95-106. https://doi.org/10.5032/ jae.2011.02095

Swanson, R. A. (2001). Assessing the financial benefits of human resource development. Cambridge, MA: Perseus.

U.S. Department of Education. (2013, June 7). Fact sheet: Redesigning America's high schools. Retrieved from http://www.ed.gov/news/pressreleases/fact-sheet-redesigning-americas-highschools

Urbaniak, G. C. \& Plous, S. (2014). Research randomizer. Retrieved from www.randomizer.org

Van Loo, J. B., \& Rocco, T. S. (2004). Continuing professional education and human capital theory. Paper presented at the Academy of Human Resource Development International Conference, 98-105. Retrieved from https://files.eric.ed.gov/ fulltext/ED492127.pdf 